\title{
TANGGUNG JAWAB NOTARIS DALAM SENGKETA PARA PIHAK TERKAIT AKTA PERJANJIAN PENGIKATAN JUAL BELI (PPJB) YANG DIBUATNYA*
}

\author{
Aulia Gumilang Rosadi \\ Program Magister Kenotariatan, Universitas Andalas, \\ Jl. Tembesi No.15 RT.02/RW.03, Kel. Rimbo Kaluang, Kec. Padang Barat, Kota Padang \\ e-mail: aulia.gumilang@gmail.com
}

\begin{abstract}
Public Notary as an official appointed by the Government who has the authority (bevoegdheid) and responsibilities which, if reviewed comprehensively, could potentially be subjected to administrative, civil or criminal claims when a dispute related to the deed which is made by him/her. The main issues discussed in this study are; 1) How chosen for a notary and parties in the binding sales purchase agreement? 2) How responsibility the parties upon an agreement in the agreement on binding sales of a bell Which is drawn up before the notary ? 3) How a form of responsibility the notary in dispute the parties related the binding sales purchase agreement made? The research is a normative juridical research with statute approach. The data used are secondary data in the form of; primary, secondary and tertiary legal materials. The results shows that the notary is administratively, civil and criminally responsible for the deed and the process of forming the deed itself, so the notary needs to implement a policy based on regulations so that he/she with the deed he/she made and the parties can be protected by law.
\end{abstract}

Keywords: Public Notary; Liability; PPJB; Dispute.

\begin{abstract}
Abstrak
Notaris sebagai pejabat umum yang ditunjuk oleh Pemerintah yang memiliki kewenangan (bevoegdheid) dan tanggung jawab yang apabila dikaji secara komprehensif, berpotensi dikenai tuntutan administratif, perdata hingga pidana saat terjadi sengketa terkait akta yang dibuatnya. Pokok permasalahan yang akan dibahas dalam penelitian ini adalah; 1) Bagaimana Kedudukan Hukum Notaris dan Para Pihak dalam Perjanjian Pengikatan Jual Beli ? 2) Bagaimana tanggungjawab para pihak atas kesepakatan dalam Perjanjian Pengikatan Jual Beli yang dibuat dihadapan notaris ? 3) Bagaimana Bentuk Pertanggungjawaban Notaris dalam sengketa Para Pihak terkait Perjanjian Pengikatan Jual Beli yang dibuatnya? Penelitian ini adalah penelitian yuridis normatif dangan pendekatan undang-undang (statute approach). Data yang digunakan adalah data sekunder yang berupa; bahan hukum primer, sekunder dan tersier. Hasil penelitian menunjukkan bahwa notaris bertanggungjawab secara administratif, perdata dan pidana terhadap akta serta proses terbentuknya akta itu sendiri, sehingga notaris perlu melaksanakan suatu kebijakan yang berlandaskan peraturan agar dirinya, akta yang dibuatnya serta para pihak dapat terlindungi secara hukum.
\end{abstract}

Kata Kunci: Notaris; Tanggungjawab; PPJB; Sengketa.

\footnotetext{
* Naskah diterima: 14 Februari 2020, direvisi: 4 Maret 2020, disetujui untuk terbit: 26 Maret 2019

Doi: $10.3376 /$ jch.v5i2.228
} 


\section{PENDAHULUAN}

Menjalankan pemerintahan, negara harus dapat hadir di tengah masyarakat dan melayani kepentingan masyarakat terkait hak-haknya sebagai warga negara sesuai dengan perundangan dan peraturan yang berlaku. Selain dengan membentuk berbagai institusi, negara juga menunjuk individu dengan profesi tertentu untuk mewakili negara dalam melayani masyarakat, salah satunya Notaris. Notaris merupakan perpanjangan tangan dari pemerintah dalam hal ini negara, dimana negara telah memberikan kepercayaan kepada notaris untuk menjalankan sebagian urusan atau tugas Negara, khususnya dalam bidang hukum perdata. Keberadaan notaris menjawab kebutuhan masyarakat akan bantuan hukum yang netral dan berimbang sehingga melindungi kepentingan hukum masyarakat. (Santia Dewi, 2011)

Jabatan Notaris lahir karena masyarakat membutuhkannya, bukan jabatan yang sengaja diciptakan kemudian baru disosialisasikan kepada khalayak. Jabatan Notaris ini tidak ditempatkan di lembaga legislatif, eksekutif ataupun yudikatif karena Notaris diharapkan memiliki posisi netral. Jabatan Notaris diadakan atau kehadirannya dikehendaki oleh aturan hukum dengan maksud untuk membantu dan melayani masyarakat yang membutuhkan alat bukti tertulis yang bersifat autentik mengenai keadaan, peristiwa atau perbuatan hukum. (Kunni Afifah, 2017)
Kedudukan notaris sebagai pejabat umum merupakan suatu jabatan terhormat yang di berikan oleh negara secara atributif melalui undang-undang kepada seseorang yang di percaya. Sebagai pejabat umum, notaris diangkat oleh menteri, berdasarkan Pasal 2 UUJN, dengan di angkatnya seorang notaris maka ia dapat menjalankan tugasnya dengan bebas, tanpa di pengaruhi badan eksekutif dan badan lainnya dan dapat bertindak netral dan independen. Tugas notaris adalah untuk melaksanakan sebagian fungsi publik dari negara dan bekerja untuk pelayanan kepentingan umum khususnya dalam bidang hukum perdata, walaupun notaris bukan merupakan pegawai negeri yang menerima gaji dari negara. (Rizki Nurmayanti, 2017) Notaris bekerja secara independen (mandiri) artinya tidak tergantung kepada atasan atau siapapun dalam menjalankan tugas dan jabatannya. Seorang notaris harus dapat memutuskan sendiri akta yang dibuat dan struktur hukum apa yang tepat serta dapat memberikan penyuluhan hukum kepada klien. (Triyanto Setyo Prabowo, 2017)

Baik dalam UUJN maupun PJ PPAT, Notaris/Pejabat Pembuat Akta Tanah dirumuskan sebagai Pejabat Umum yang berwenang untuk membuat akta autentik. Dalam hal ini yang dimaksud berwenang adalah meliputi berwenang terhadap orangnya, yaitu untuk kepentingan siapa akta itu dibuat atau dikehendaki oleh orang yang berkepentingan. Berwenang terhadap aktanya, yaitu yang berwenang membuat akta autentik mengenai semua 
perbuatan, perjanjian dan ketetapan yang diharuskan Undang-Undang atau yang dikehendaki yang bersangkutan, serta berwenang terhadap waktunya dan berwenang terhadap tempatnya, yaitu sesuai tempat kedudukan dan wilayah Jabatan Pejabat yang bersangkutan dan menjamin kepastian waktu para penghadap yang tercantum dalam akta. (Habib Adjie, 2009)

Kekuatan akta autentik maupun akta Notaris merupakan akibat langsung dari adanya tugas-tugas pejabat Notaris yang diberikan oleh ketentuan Perundang undangan. Bahwa dalam hubungan hukum harus ada keterangan-keterangan autentik yang berguna sebagai alat pembuktian bagi pihak-pihak yang memberikan keterangan dan dituangkan ke dalam akta Notaris sehingga menjadi akta autentik. (Rahmawati Boty, 2017)

Suatu akta autentik mempunyai kekuatan pembuktian lahiriah (kekuatan yang membuktikan bahwa akta autentik tersebut kehadirannya telah sesuai dengan perundang-undangan yang berlaku), formal (yang dinyatakan dalam akta autentik tersebut adalah benar sepanjang tidak dapat dibuktikan bahwa hal tersebut tidak benar) dan material (memberikan kepastian hukum bahwasanya keterangan yang diberikan akta tersebut adalah benar). (Annisa, 2019)

Untuk mewujudkan keadilan hukum sebagai tujuan hukum, notaris dalam membuat akta wajib memperhatikan kedudukan yang seimbang bagi para pihak dan wajib pula memperhatikan substansi akta agar tidak bertentangan dengan nilai-nilai keadilan sosial (tahap pra kontraktual dan kontraktual), sedangkan untuk mewajibkan kepastian hukum notaris wajib memperhatikan mekanisme dan/atau tata cara pembuatan akta notarill. Notaris wajib pula memperhatikan substansi akta agar tidak bertentangan dengan hukum yang berlaku (tahap kontraktual), karena dengan terwujudnya kedua tujuan hukum tersebut, kemanfaatan dapat dirasakan oleh para pihak dan pihak lain yang berkepentingan. (Benny Krestian Heriawanto, 2018)

Akta notariil yang merupakan perjanjian para pihak mengikat bagi mereka yang membuatnya. Oleh karena itu, syarat-syarat sahnya suatu perjanjian harus dipenuhi. Syarat-syarat tersebut meliputi syarat subjektif yang berkaitan dengan subjek yang mengadakan atau membuat perjanjian, dan syarat objektif yang berkaitan dengan objek perjanjian. Syarat sahnya perjanjian harus diwujudkan dalam akta notariil. Syarat subjektif dicantumkan dalam awal akta, dan syarat objektif dicantumkan dalam badan akta sebagai isi akta. (Nur Aini, 2019)

Mengingat akan pentingnya akta autentik ini, seorang notaris hendaknya harus dapat memenuhi maksud dan kehendak masyarakat serta negara yang dibebankan kepadanya untuk dapat memberikan kepastian dan perlindungan hukum terhadap perbuatan hukum yang dilakukan. Dengan cara membuat akta autentik untuk menjamin kepastian peristiwa atau perbuatan hukum yang 
dilakukan. Untuk itu seorang notaris harus memperhatikan hal-hal penting yang mutlak harus terpenuhi dalam pembuatan sebuah akta autentik untuk dapat memiliki kekuatan pembuktian yang sempurna. Unsur verlidjen suatu akta menjadi satu hal penting yang harus dipenuhi terlebih dahulu oleh seorang notaris dalam pembuatan sebuah akta. (Rita Alfiana, 2018)

Pentingnya peranan notaris dalam membantu menciptakan kepastian dan perlindungan hukum bagi masyarakat, lebih bersifat preventif, atau bersifat pencegahan terjadinya masalah hukum, dengan cara penerbitan akta autentik yang dibuat di hadapannya terkait dengan status hukum, hak dan kewajiban seseorang dalam hukum, dan lain sebagainya, yang berfungsi sebagai alat bukti yang paling sempurna di Pengadilan, dalam hal terjadi sengketa hak dan kewajiban yang terkait. (Sjaifurrachman, 2011)

Dari beberapa akta perjanjian yang dibuat, perjanjian jual beli tanah banyak ditemui dalam keseharian tugas notaris. Tanah merupakan benda tak bergerak yang telah menjadi kebutuhan mendasar dalam kehidupan manusia. Tanah dapat difungsikan sebagai tempat mendirikan rumah tinggal, tempat usaha ataupun sebagai sarana investasi. Hak atas tanah dapat diperoleh dari berbagai cara, salah satunya diperoleh melalui jual beli. Jual beli pada prinsipnya merupakan suatu perjanjian, perjanjian yang nantinya akan berujung kepada penyerahan (levering) atas benda tidak bergerak yakni tanah tunduk pada beberapa peraturan tersendiri terutama peralihan hak dan pendaftaran haknya. (Yudhi Setiawan, 2009)

Bantuan notaris para pihak yang membuat perjanjian pengikatan jual beli akan mendapatkan bantuan dalam merumuskan hal-hal yang akan diperjanjikan. Namun, suatu perjanjian tidak selalu dapat berjalan sesuai dengan kesepakatan yang diinginkan oleh para pihak. Dalam kondisi tertentu dapat ditemukan terjadinya berbagai hal, yang berakibat suatu perjanjian mengalami pembatalan, baik dibatalkan oleh para pihak maupun atas perintah pengadilan. (R. Setiawan, 2005)

Demi kelancaran administrasi mengenai kegiatan jual beli, Notaris membuat suatu akta pengikatan jual beli agar pihak-pihak saling terikat (sebelum dibuatkan Akta Jual Beli oleh Pejabat Pembuat Akta Tanah, selanjutnya disebut PPAT) sebagai syarat adanya transaksi jual beli tanah dan/atau bangunan. (Silviana, A. 2017) Pengikatan tersebut lahir disebabkan belum dipenuhinya unsur-unsur untuk menjual atau untuk membeli tanah sehingga proses diselesaikannya transaksi menjadi tersendat. Tidak ditemukan suatu pembeda antara perjanjian secara umum dengan perjanjian jual beli yang hadir berdasarkan keterbukaan Buku III KUHPerdata dengan pemberian sebebasbebasnya serta sebesar-besarnya terhadap subjek hukum dalam melaksanakan persetujuan tanpa mempermasalahkan isi dan bentuknya dengan tetap mengindahkan aturan hukum, agama, dan 
tata susila. Pada umumnya, suatu perjanjian mengenai tanah terkandung unsur-unsur wajib sebelum bisa dilaksanakannya perjanjian pokok sehingga tercapai tujuan akhir bagi pihakpihak. (Baswedan, T. B. T. 2014)

Tanah merupakan salah satu bagian dari kekayaan alam yang ada di bumi yang sangat vital keberadaannya bagi semua kehidupan di bumi khususnya bagi manusia. Tanah memiliki nilai tinggi karena mempunyai peran serta fungsi penting dan tidak dapat dipisahkan dari kehidupan manusia. Kebutuhan akan tanah menjadi kebutuhan yang melekat dan tidak dapat dipisahkan dari kehidupan manusia sehingga membuat manusia cenderung memiliki keinginan untuk menguasai dan memiliki tanah. (Dwi Apriliana, 2018)

Perjanjian pengikatan jual beli (PPJB) lahir sebagai akibat terhambatnya atau terdapatnya beberapa persyaratan yang ditentukan oleh undang-undang yang berkaitan dengan jual beli hak atas tanah yang akhirnya agak menghambat penyelesaian transaksi dalam jual beli hak atas tanah. Persyaratan tersebut ada yang lahir dari peraturan perundang-undangan yang ada dan ada pula yang timbul sebagai kesepakatan para pihak yang akan melakukan jual beli hak atas tanah. Persyaratan yang timbul dari undangundang misalnya jual beli harus telah lunas baru Akta Jual Beli (AJB) dapat ditanda tangani. Pada umumnya persyaratan yang sering timbul adalah persyaratan yang lahir kesepakatan para pihak yang akan melakukan jual beli, misalnya pada waktu akan melakukan jual beli, pihak pembeli menginginkan adanya sertifikat hak atas tanah yang akan dibelinya sedangkan hak atas tanah yang akan dijual belum mempunyai sertifikat, dan di sisi lain misalnya, pihak pembeli belum mampu untuk membayar semua harga hak atas tanah secara lunas, sehingga baru dibayar setengah dari harga yang disepakati. (Rusdianto, 2009)

PPJB bersifat mengikat bagi para pihak untuk menunjukkan keseriusan para pihak dalam melakukan transaksi jual beli hak atas tanah dan bangunan, dimana pada saatnya nanti keseriusan tersebut akan ditandai dengan pemenuhan asas tunai dan terang berupa pelunasan secara keseluruhan terhadap pembelian hak atas tanah dan kemudian dilakukannya penandatanganan Akta Jual Beli (AJB) dihadapan Pejabat Pembuat Akta Tanah (PPAT), agar selanjutnya diteruskan dengan melakukan pendaftaran atas peralihan hak atas tanah ke Kantor Pertanahan Kota/Kabupaten setempat, untuk kemudian dicatatkan (balik nama) kepemilikan baru hak atas tanah ke dalam buku tanah yang tersimpan di Badan Pertanahan Nasional (BPN). Adapun kewenangan pembuatan akta PPJB berada ditangan Notaris. (Kadek Dio Anjasmara, 2019).

Pengikatan Jual Beli (PJB) tanah antara para pihak dapat dilakukan melalui akta di bawah tangan atau dapat pula dilakukan melalui suatu akta yang dibuat di hadapan notaris. Untuk tanah-tanah yang bersertifikat Hak Milik (SHM) maupun tanah yang belum memiliki 
Sertifikat Hak Milik (SHM) pengikatan jual belinya dapat dilakukan di hadapan notaris. Pengikatan jual beli tanah dengan status Sertifikat Hak Milik merupakan perbuatan hukum awal yang mendahului perbuatan hukum jual beli tanah. Jadi pengikatan jual beli berbeda dengan perbuatan hukum jual beli tanah. Notaris memiliki wewenang membuat akta pengikatan jual beli tanah dengan status Sertifikat Hak Milik (SHM) tapi tidak berwenang membuat akta autentik jual beli tanah bersertifikat hak milik (AJB), karena kewenangan membuat akta Jual Beli Tanah (AJB) bersertifikat Hak Milikada pada Pejabat Pembuat Akta Tanah (PPAT). (Muchlis Patahna, 2009)

Pengikatan jual beli tanah dengan status Sertifikat Hak Milik merupakan perbuatan hukum awal yang mendahului perbuatan hukum jual beli tanah. Jadi, pengikatan jual beli berbeda dengan perbuatan hukum jual beli tanah. Notaris memiliki wewenang membuat akta pengikatan jual beli tanah dengan status Sertifikat Hak Milik (SHM) tapi tidak berwenang membuat akta autentik jual beli tanah bersertifikat hak milik, karena kewenangan membuat akta Jual Beli Tanah (AJB) bersertifikat Hak Milik ada pada Pejabat Pembuat Akta Tanah (PPAT). (Muchlis Patahna, 2009)

Apabila terjadi persyaratan jual beli hak atas tanah yang belum dipenuhi maka penandatanganan para pihak terhadap Akta Jual Beli hak atas tanah belum dapat dilakukan di hadapan Pejabat Pembuat Akta Tanah. Keadaan yang seperti ini tentu tidak menguntungkan atau bahkan dapat merugikan para pihak yang melakukan jual beli hak atas tanah. Keadaan tersebut membuat pihak penjual harus menunda dulu penjualan tanahnya, agar persyaratan tersebut dapat terpenuhi. Hal yang sama juga berlaku terhadap pihak pembeli, dengan keadaan tersebut pihak pembeli juga tertunda keinginannya untuk mendapatkan hak atas tanah yang akan dibelinya. Untuk mengatasi hal tersebut, dan untuk kelancaran tertib administrasi pertanahan, maka ditemukan suatu inovasi hukum yaitu dengan dibuatnya Akta Perjanjian Pengikatan Jual Beli (PPJB), meskipun isinya mengenai jual beli namun formatnya hanya sebatas perjanjian pengikatan jual beli hak atas tanah yang dilakukan di hadapan notaris. (Alfiansyah, 2017)

Pelaksanaannya, PPJB tidaklah semudah dan sesederhana perjanjianperjanjian biasanya. Di beberapa sengketa para pihak yang ada terkait sebuah PPJB, notaris terkadang seakan ditarik untuk ikut bertanggungjawab karena hal yang berhubungan dengan Akta itu sendiri, maupun proses peralihan akta pengikatan perjanjian bual beli menjadi sebuah akta jual beli. Sebagai contoh; 1) Kasus Dugaan Tindak Pidana Penggelapan dalam Jabatan yang didakwakan kepada Notaris Elfita Achtar sebagaimana Perkara No: 53/Pid.B/2017 PN.Bkt, di Bukittinggi, 2) Kasus Notaris Theresia Pontoh dalam dugaan tindak pidana penggelapan di Irian Jaya.

Guna menghindari adanya pelanggaran-pelanggaran yang dapat mengarah kepada tindakan notaris yang 
Aulia Gumilang Rosadi: Tanggung Jawab Notaris Dalam Sengketa Para Pihak Terkait...

dapat dijerat oleh pasal-pasal pemidanaan, notaris dalam membuat akta autentik khususnya PPJB harus senantiasa memperhatikan kaidah-kaidah hukum yang berlaku, diantaranya notaris dalam menjalankan jabatannya sebagai Pejabat Umum harus memperhatikan UndangUndang No. 2 Tahun 2014 tentang Perubahan Atas Undang-undang Nomor 30 Tahun 2004 tentang Jabatan Notaris (UUJN), peraturan turunan dari undangundang tersebut, serta aturan-aturan terkait seperti Kode Etik Notaris dan sebagainya.

Berdasarkan UUJN, notaris sebagai pejabat umum kepadanya dapat dituntut tanggung jawab terhadap akta yang dibuatnya. Apabila akta yang dibuat dibelakang hari mengandung sengketa maka hal ini perlu dipertanyakan, apakah akta itu merupakan kesalahan notaris atau kesalahan para pihak yang tidak memberikan dokumen dengan sebenarbenarnya dan para pihak memberikan keterangan yang tidak benar diluar sepengetahuan notaris atau adanya kesepakatan yang dibuat antara notaris dengan salah satu pihak yang menghadap. Apabila akta yang dibuat notaris mengandung cacat hukum karena kesalahan notaris baik karena kelalaian maupun kesengajaan notaris itu sendiri, maka notaris itu harus memberikan pertanggung jawaban baik secara moral maupun secara hukum. Agar notaris dan para pihak terhindar dari sengketasengketa yang akan timbul di kemudian hari atas akta yang dibuatnya, khususnya akta PPJB, terlebih PPJB yang dibuat tersebut dapat menjerat notaris ke ranah pidana, notaris perlu lebih hati-hati dan teliti dalam membuat PPJB. Selain itu, notaris sebagai pejabat umum yang bertanggung jawab atas akta yang dibuatnya perlu mengkaji tentang status hukum dirinya sebagai pejabat umum berdasarkan Undang-undang, serta status hukum para pihak yang datang menghadap kepadanya guna menghindari dan meminimalisir potensi-potensi yang akan menimbulkan sengketa-sengketa terhadap akta yang dibuat oleh notaris tersebut.

Berdasarkan latar pemikiran di atas, maka permasalahan yang akan diteliti dapat dirumuskan sebagai berikut: Bagaimana Kedudukan Hukum Notaris dan Para Pihak dalam Perjanjian Pengikatan Jual Beli (PPJB)? Bagaimana tanggungjawab para pihak atas kesepakatan dalam Perjanjian Pengikatan Jual Beli yang dibuat di hadapan Notaris? Bagaimana Bentuk Pertanggungjawaban Notaris dalam sengketa Para Pihak terkait Perjanjian Pengikatan Jual Beli (PPJB) yang dibuatnya?.

\section{METODE PENELITIAN}

Pendekatan penelitian yang hendak dipergunakan dalam penelitian ini adalah pendekatan hukum normatif (yuridis normatif), maka dapat dilakukan lebih dari satu pendekatan. (Jhony Ibrahim, 2006) Dalam penelitian ini, digunakan pendekatan perundang-undangan (Statue Aproach) dan pendekatan konsep (Concept Aproach). (Abdul Kadir Muhammad, 2004). Penelitian ini adalah suatu penelitian yang bersifat deskriptif. 
berupa pemaparan dan bertujuan untuk memperoleh gambaran lengkap tentang keadaan hukum. Pilihan pendekatan dalam penelitian ini adalah menggunakan pendekatan penelitian hukum doktrinal (doctrinal legal research). Sumber datanya berupa bahan hukum primer, bahan hukum sekunder dan bahan hukum tersier.

\section{HASIL DAN PEMBAHASAN}

\section{Kedudukan Hukum Notaris dan Para Pihak dalam Perjanjian Pengikatan Jual Beli (PPJB)}

Akta yang dibuat oleh notaris berkedudukan sebagai akta autentik menurut bentuk dan tata cara yang ditetapkan UUJN. Ada 2 (dua) dua akta notaris, yaitu:

1. Akta yang dibuat oleh notaris (akta relaas)

Akta relaas adalah akta yang dibuat notaris atas permintaan para pihak, agar notaris mencatat atau menuliskan segala sesuatu hal yang dibicarakan oleh pihak yang berkaitan dengan tindakan hukum atau tindakan lainnya yang dilakukan oleh para pihak, agar tindakan tersebut dituangkan dalam suatu akta notaris.

2. Akta yang dibuat di hadapan notaris (akta partij)

Akta partij) adalah akta yang dibuat dihadapan notaris atas permintaan para pihak, notaris berkewajiban untuk mendengarkan pernyataan atau keterangan para pihak yang dinyatakan atau diterangkan sendiri oleh para pihak di hadapan notaris. (Habib Adjie, 2008)

Setelah perjanjian pengikatan jual beli memuat semua keinginan para pihak maka ditandatangani oleh para pihak, 2 (dua) orang saksi dan Notaris yang bersangkutan. Perjanjian pengikatan jual beli yang dibuat oleh notaris dituangkan secara jelas perbuatan hukum apa yang dilakukan oleh para pihak. Dengan telah ditanda tanganinya akta perjanjian pengikatan jual beli (PPJB) maka perjanjian itu mengikat kedua belah pihak dan berlaku sebagai undang-undang bagi para pihak. Hal ini telah ditegaskan dalam Pasal 1338 KUHPerdata, menyatakan:

Semua perjanjian yang dibuat secara sah berlaku sebagai undang-undang bagi mereka yang membuatnya. Suatu perjanjian tidak dapat ditarik kembali selain dengan kesepakatan kedua belah pihak, atau karena alasan-alasan yang oleh undangundang dinyatakan cukup untuk itu.

Suatu perjanjian harus dilaksanakan dengan itikad baik.

Pasal 1338 KUHPerdata juga dikatakan suatu perjanjian harus dilakukan dengan itikad baik, maksudnya pada saat mulai berlakunya suatu hubungan hukum dipenuhinya syaratsyarat untuk dimulainya hubungan hukum (perjanjian jual beli) dan pada waktu pelaksanaan hak dan kewajiban para pihak harus melaksanakannya sesuai yang telah disepakati dan ditandatangani dalam akta perjanjian pengikatan jual beli.

Perjanjian pengikatan jual beli ini beberapa pihak yang terlibat selain notaris yaitu penjual dan pembeli yang mempunyai kedudukan yang berbeda. Adapun kedudukan para pihak dan notaris dalam perjanjian pengikatan jual beli, sebagai berikut: 
Aulia Gumilang Rosadi: Tanggung Jawab Notaris Dalam Sengketa Para Pihak Terkait...

1. Notaris.

Kedudukan notaris dalam perjanjian pengikatan jual beli adalah:

a. Notaris sebagai pejabat umum yang berwenang membuat akta autentik yang berhubungan perbuatan, perjanjian dan ketetapan yang dikehendaki para pihak sebagaimana yang diatur dalam Pasal 15 ayat (1), (2) UUJN.

b. Notaris menuangkan apa yang dikendaki oleh para pihak asal tidak bertentangan dengan peraturan perundang-undangan.

c. Notaris memastikan apa yang menghambat tidak bisa ditandatangani akta jual beli harus selesai sebelum akta jual beli ditandatangani, misalnya: pembayaran harga transaksi jual beli belum lunas maka harus dilunasi saat ditandatangani akta jual beli.

2. Penjual

Kedudukan penjual dalam perjanjian pengikatan jual beli, sebagai berikut:

a. Penjual harus menjamin bahwa tanah dan bangunan yang menjadi objek dari perjanjian pengikatan jual beli:

1) Tidak sedang terlibat sengketa apapun.

2) Tidak dikenakan suatu sitaan.

3) Adalah miliknya Pihak Pertama dan hanya bisa dipindahtangankan oleh Pihak Pertama.

4) Tidak sedang dijaminkan untuk menjamin suatu hutang berupa apapun

b. Memberikan keterangan dan identitas yang benar kepada notaris. c. Melaksanakan kewajiban-kewajiban yang telah diatur dalam perjanjian pengikatan jual beli, misalnya: pemegang haknya sudah meninggal sehingga ada proses turun waris yang bertindak dalam perjanjian pengikatan jual beli adalah semua ahli waris. Ahli waris harus menyelesaikan proses turun waris baik kelengkapan untuk pengurusan waris ke atas nama ahli waris.

d. Penjual tidak boleh melakukan tindakan-tindakan yang dengan nyata melanggar perjanjian pengikatan jual beli tanah, misalnya menjual obyek dari perjanjian tersebut kepada pihak lain.

3. Pembeli.

Kedudukan pembeli dalam perjanjian pengikatan jual beli adalah melakukan kewajiban-kewajiban yang tercantum dalam perjanjian pengikatan jual beli, misalnya melakukan pembayaran jual beli apabila pembayaran dilakukan secara bertahap.

2. Tanggungjawab Para Pihak Atas Kesepakatan Dalam Perjanjian Pengikatan Jual Beli Yang Dibuat Di Hadapan Notaris

PPJB yang mengatur hak dan kewajiban penjual dan pembeli secara otomatis mereka harus bertanggungjawab terhadap apa yang telah diatur dalam PPJB tersebut. Adapun tanggungjawab penjual dan pembeli dalam PPJB yang dibuat di hadapan notaris, sebagai berikut:

1. Pihak penjual

Perjanjian pengikatan jual beli ini dilakukan karena masih ada syarat-syarat 
yang belum dipenuhi untuk dilakukannya jual beli. Syarat-syarat tersebut juga harus dilengkapi oleh penjual sebagai pemegang hak dan penjual bertanggungjawab memenuhinya. Misalnya:

a. Jangka waktu sertifikat masih hak guna bangunan dan pembeli ingin membeli dengan status hak milik.

b. Sertifikat belum dipecah.

c. Pemegang hak meninggal dunia.

d. Sertifikat masih di bank .

e. Sertifikat dengan status tanah milik kaum (harus dilampirkan ranji kaum dan kesepakatan kaum yang diketahui oleh Mamak Kepala Waris)

Apabila penjual tidak melengkapi persyaratan tersebut sesuai dengan jangka waktu yang telah disepakati atau diberikan, maka pembeli tidak akan melunasi sisa pembayaran karena pembeli akan melunasi jika semua syarat telah dilengkapi.

2. Pihak pembeli

Pembeli bertanggungjawab untuk melunasi sisa pembayaran jual beli kepada penjual apabila penjual telah melengkapi persyaratan yang menyebabkan belum bisa dilakukan jual beli di hadapan PPAT.

Penjual dan pembeli harus bertanggungjawab terhadap apa yang telah disepakati dan di tuangkan dalam PPJB. Apabila penjual dan pembeli tidak bertanggungjawab terhadap apa yang telah disepakati maka para pihak disebut telah melakukan wanprestasi karena apa yang telah dituangkan dalam PPJB itu mengikat kedua belah pihak dan berlaku sebagai aturan bagi para pihak. PPJB ini berfungsi sebagai alat pembuktian apabila salah satu pihak wanprestasi dan untuk menuntut berdasarkan pada pasal- pasal yang telah disepakati. Bentuk-bentuk wanprestasi yang dapat terjadi dalam perjanjian pengikatan jual beli tanah antara lain:

a. Penjual lama melakukan pengurusan yang menyebabkan terhambatnya untuk dilakukan AJB, misalnya: proses turun waris.

b. Pembeli menunda-nunda pembayaran harga tanah yang seharusnya telah dibayar atau baru membayar sekian hari setelah tanggal jatuh tempo, ataupun pembeli melakukan pembayaran tetapi tidak sebagaimana yang diperjanjikan.

c. Pembeli tidak membayar denda atas keterlambatannya membayar harga tanah itu atau terlambat membayar denda itu.

PPJB yang dibuat oleh notaris harus menuangkan secara jelas perbuatan hukum apa yang dilakukan oleh para pihak, yang ingin dibuktikan dan diketahui dari akta yang dibuat. Akta yang dibuat oleh Notaris jangan sampai memuat rumusan-rumusan yang dapat menimbulkan sengketa karena tidak lengkap dan jelas. Pada prinsipnya akta dibuat sebagai alat bukti yang fungsinya untuk memastikan bahwa telah terjadi suatu perbuatan hukum tentang apa yang dilakukan oleh pihak-pihak dalam akta tersebut. 
Aulia Gumilang Rosadi: Tanggung Jawab Notaris Dalam Sengketa Para Pihak Terkait...

\section{Bentuk Pertanggungjawaban Notaris dalam sengketa Para Pihak terkait Perjanjian Pengikatan Jual Beli (PPJB) yang dibuatnya}

Sebagai pejabat umum (openbaar ambtenaar) notaris berwenang membuat akta autentik. Sehubungan dengan kewenangannya tersebut notaris dapat dibebani tanggung jawab atas perbuatannya/pekerjaannya dalam membuat akta autentik. Tanggung jawab notaris sebagai pejabat umum meliputi tanggung jawab profesi notaris itu sendiri yang berhubungan dengan akta, diantaranya: (M. Nur Rasaid, 2005)

a. Tanggung jawab notaris secara perdata atas akta yang dibuatnya, dalam hal ini adalah tanggung jawab terhadap kebenaran materil akta, dalam konstruksi perbuatan melawan hukum. Perbuatan melawan hukum di sini dalam sifat aktif maupun pasif. Aktif, dalam artian melakukan perbuatan yang menimbulkan kerugian pada pihak lain. Sedangkan pasif, dalam artian tidak melakukan perbuatan yang merupakan keharusan, sehingga pihak lain menderita kerugian. Jadi unsur dari perbuatan melawan hukum di sini yaitu adanya perbuatan melawan hukum, adanya kesalahan dan adanya kerugian yang ditimbulkan. Perbuatan melawan hukum di sini diartikan luas, yaitu suatu pebuatan tidak saja melanggar undang-undang, tetapi juga melanggar kepatutan, kesusilaan atau hak orang lain dan menimbulkan kerugian. Suatu perbuatan dikategorikan perbuatan melawan hukum apabila perbuatan tersebut:

1) Melanggar hak orang lain;
2) Bertentangan dengan aturan hukum;

3) Bertentangan dengan kesusilaan;

4) Bertentangan dengan kepatutan dalam memperhatikan kepentingan diri dan harta orang lain dalam pergaulan hidup sehari-hari.

b. Tanggung jawab notaris secara pidana atas akta yang dibuatnya. Pidana dalam hal ini adalah perbuatan pidana yang dilakukan oleh seorang notaris dalam kapasitasnya sebagai pejabat umum yang berwenang membuat akta, bukan dalam konteks individu sebagai warga negara pada umumnya. Unsur-unsur dalam perbuatan pidana meliputi:

1) Perbuatan manusia;

2) Memenuhi rumusan peraturan perundang-undangan, artinya berlaku asas legalitas, nullum delictum nulla poena sine praevia lege poenali (tidak ada perbuatan yang dilarang dan diancam dengan pidana jika hal tersebut tidak atau belum dinyatakan dalam undangundang);

3) Bersifat melawan hukum.

4) Tanggung jawab notaris berdasarkan Undang-undang Jabatan Notaris (UUJN).

5) Tanggung jawab notaris dalam menjalankan tugas jabatannya berdasarkan kode etik notaris. Hal ini ditegaskan dalam pasal 4 UUJN tentang sumpah jabatan notaris.

Mempertanggungjawabkan terhadap akta PPJB yang dibuatnya, notaris dapat dipanggil untuk menghadiri sidang pada Pengadilan Negeri tetapi notaris juga harus merahasiakan terhadap akta yang dibuatnya sesuai dengan sumpah/janji jabatan kecuali undang-undang yang 
menentukan. Hal ini ditentukan UUJN, sebagai berikut:

1) Pasal 16 ayat (1) UUJN menyatakan:

Dalam menjalankan jabatannya, notaris antara lain berkewajiban merahasiakan segala sesuatu mengenai akta yang dibuatnya dan segala keterangan yang diperoleh guna pembuatan akta sesuai dengan sumpah/janji jabatan, kecuali Undang-Undang menentukan lain.

2) Pasal 54 UUJN, menyatakan:

Notaris hanya dapat memberikan, memperlihatkan, atau memberitahukan isi akta, grosse akta, salinan akta atau kutipan akta kepada orang yang berkepentingan langsung pada akta, ahli waris, atau orang yang memperoleh hak, kecuali ditentukan lain oleh peraturan perundang-undangan.

Selain diatur dalam UUJN mengenai merahasiakan akta yang dibuat oleh Notaris, diatur juga dalam Pasal 1909 ayat (2) huruf 3e KUHPerdata:

Segala siapa yang karena kedudukannya, pekerjaannya atau jabatannya menurut Undang-Undang, diwajibkan merahasiakan sesuatu, namun hanyalah semata-mata mengenai hal-hal yang pengetahuannya dipercayakan kepadanya sebagai demikian.

Pemanggilan notaris sebagai saksi, tersangka dalam permasalahan yang timbul dari akta yang dibuat notaris haruslah memperoleh persetujuan dari Majelis Kehormatan Notaris. Hal ini diatur dalam Pasal 66 UUJN yang menyatakan bahwa:

1) Untuk kepentingan proses peradilan, penyidik, penuntut umum, atau hakim dengan persetujuan Majelis Pengawas Daerah berwenang:

a. mengambil fotokopi Minuta Akta dan/atau surat-surat yang dilekatkan pada Minuta Akta atau Protokol Notaris dalam penyimpanan Notaris; dan

b. memanggil Notaris untuk hadir dalam pemeriksaan yang berkaitan dengan akta yang dibuatnya atau Protokol Notaris yang berada dalam penyimpanan Notaris.

2) Pengambilan fotokopi Minuta Akta atau surat-surat sebagaimana dimaksud pada ayat (1) huruf a, dibuat berita acara penyerahan.

Pasal 66 UUJN dalam praktik hukum baik Majelis Pengawas Daerah maupun Penyidik tetap memberlakukan ketentuan Pasal 66 bagi Notaris yang cuti yang dipanggil untuk keperluan pemeriksaan dalam suatu perkara pidana, berkaitan dengan akta yang dibuatnya. Selain dilindungi dalam Pasal 66 UUJN, Ikatan Notaris Indonesia juga membuat $\mathrm{MoU}$ dengan Kapolri, yang menegaskan bahwa pemanggilan Notaris pihak kepolisian harus seizin dari Majelis Pengawas Daerah. Namun dalam jangka waktu UUJN Nomor 30 Tahun 2004 belum dirubah, terhadap Pengawasan Notaris menjadi bagian yang diperjuangkan untuk direvisi, maklum saja fungsi ini menyangkut kelangsungan hidup setiap Notaris atau jabatannya dicabut atas kesalahan yang dilakukannya. (Zulkifli Harahap, 2011)

Menurut Laurensius Arliman S, Pasal 66 UUJN, seperti imunitas bagi seorang Notaris dalam menjalankan jabatannya sebagai pejabat umum yang berwenang 
Aulia Gumilang Rosadi: Tanggung Jawab Notaris Dalam Sengketa Para Pihak Terkait...

membuat akta autentik. Apabila terjadi kesalahan baik dari kesalahan kecil maupun fatal, semunya harus izin dari MPD wilayah kerja Notaris. (Laurensius Arliman S, 2016)

Prinsip pertanggungjawaban berdasarkan besar dan kecilnya suatu kesalahan dijadikan sebagai landasan untuk menjatuhkan sanksi kepada notaris. Pertanggungjawaban berdasarkan unsur kesalahan (fault liability atau liability based on fault) ialah prinsip yang biasa digunakan hukum perdata, khususnya di dalam Pasal 1365, 1366, dan 1367 KUHPerdata. Prinsip ini menjelaskan bahwa seseorang dapat dimintai pertanggungjawaban secara hukum, jika terdapat kesalahan yang dilakukan olehnya. Pasal 1365 KUHPerdata menjelaskan tentang perbuatan melawan hukum, di dalam pasal ini mengharuskan adanya empat unsur pokok kesalahan, yaitu adanya suatu perbuatan melawan hukum, adanya suatu unsur kesalahan, adanya suatu kerugian yang diderita, dan adanya suatu hubungan kausalitas antara kesalahan dan kerugian. Kesalahan adalah unsur yang bertentangan dengan hukum atau pelanggaran hukum. Pelanggaran hukum tidak hanya bertentangan dengan undang-undang, tetapi juga bertentangan dengan kepatutan dan kesusilaan. (Tengku Erwinsyahbana, 2018)

Selain UUJN, Notaris memiliki pedoman atau pegangan dalam menjalankan jabatannya, yaitu Kode Etik. Di dalam Kode Etik setiap Notaris yang menjalankan jabatannya tidak boleh bertentangan dengan peraturan yang telah di buat oleh pihak yang berwenang. Kode etik Notaris merupakan suatu kaidah moral yang ditentukan oleh perkumpulan Ikatan Notaris Indonesia berdasarkan Keputusan Kongres perkumpulan dan/atau yang ditentukan dan diatur dalam peraturan perundang-undangan dan berlaku bagi serta wajib ditaati oleh individu dan semua anggota perkumpulan dan semua orang yang menjalankan tugas dan jabatan Notaris. Di dalam kode etik sangat menjunjung dan memberi penghormatan terhadap martabat manusia pada umumnya dan martabat Notaris pada khususnya. Atas dasar penghormatan tersebut maka profesi Notaris memiliki karakter mandiri, tidak memihak, tidak meminta pamrih, rasionalitas maksudnya mengacu kepada kebenaran obyektif, spesifitas fungsional serta memiliki rasa kebersamaan yang positif antar sesama rekan Notaris. (Ariy Yandillah, 2015)

Salah satu yang perlu dilakukan untuk memelihara keluhuran jabatan notaris adalah dengan melakukan pengawasan sekaligus penegakan kode etik terhadap notaris. Pengawasan dapat diartikan secara sempit dan secara luas. Pengawasan dalam artian sempit yang penulis maksudkan di sini adalah bahwa notaris melakukan pengawasan demi upaya pencegahan terhadap pelanggaran kode etik notaris, sedangkan pengawasan secara luas tidak hanya pengawasan dalam rangka pencegahan, namun termasuk di dalamnya upaya-upaya penegakan kode etik, sehingga pengawasan tersebut menjadi suatu kesatuan sistem dalam mewujudkan 
keluhuran profesi notaris. Pengawasan yang dimaksudkan dalam tulisan ini adalah bentuk pengawasan secara luas yang mencakup upaya pencegahan maupun upaya penegakan hukumnya. (Nisaul Hasanah, 2018)

Berdasarkan hal tersebut di atas penulis berpendapat bahwa dalam menjalankan tugas dan tanggung jawabnya seorang notaris harus berpegang teguh pada peraturan perundangundangan yang berlaku demi terciptanya tujuan hukum. Profesi notaris merupakan profesi mandiri yang menuntut penuh pertanggung jawaban sehingga apabila seorang notaris melakukan kesalahan maka ia harus siap menanggung segala resiko yang timbul dari kesalahan yang dibuatnya. Maka dari itu dalam melaksanakan tugasnya harus menerapkan prinsip kehati-hatian agar tidak terjadi permasalahan hukum di masa yang akan datang.

\section{SIMPULAN}

Berdasarkan uraian di atas, maka penulis menarik kesimpulan sebagai berikut:

1. Kedudukan Hukum Notaris dan Para Pihak dalam Perjanjian Pengikatan Jual Beli (PPJB) mempunyai kedudukan yang berbeda. Kedudukan hukum Notaris sebagai pejabat umum yang berwenang membuat akta outentik yang berhubungan perbuatan, perjanjian dan ketetapan yang dikehendaki para pihak sebagaimana yang diatur dalam Pasal 15 ayat (1), (2) UUJN. Notaris menuangkan apa yang dikendaki oleh para pihak asal tidak bertentangan dengan peraturan perundangundangan. Notaris memastikan apa yang menghambat tidak bisa ditandatangani akta jual beli harus selesai sebelum akta jual beli ditandatangani, misalnya: pembayaran harga transaksi jual beli belum lunas maka harus dilunasi saat ditandatangani akta jual beli. Kedudukan penjual dalam perjanjian pengikatan jual beli , adalah Penjual harus menjamin bahwa tanah dan bangunan yang menjadi objek dari perjanjian pengikatan jual beli tidak sedang terlibat sengketa apapun, tidak dikenakan suatu sitaan, miliknya Pihak Pertama dan hanya bisa dipindahtangankan oleh Pihak Pertama, tidak sedang dijaminkan untuk menjamin suatu hutang berupa apapun, memberikan keterangan dan identitas yang benar kepada notaris. Melaksanakan kewajiban-kewajiban yang telah diatur dalam perjanjian pengikatan jual beli, misalnya: pemegang haknya sudah meninggal sehingga ada proses turun waris yang bertindak dalam perjanjian pengikatan jual beli adalah semua ahli waris. Ahli waris harus menyelesaikan proses turun waris baik kelengkapan untuk pengurusan waris ke atas nama ahli waris. Penjual tidak boleh melakukan tindakan-tindakan yang dengan nyata melanggar perjanjian pengikatan jual beli tanah, misalnya menjual obyek dari perjanjian tersebut kepada pihak 
Aulia Gumilang Rosadi: Tanggung Jawab Notaris Dalam Sengketa Para Pihak Terkait...

lain. Kedudukan hukum pembeli dalam perjanjian pengikatan jual beli adalah melakukan kewajibankewajiban yang tercantum dalam perjanjian pengikatan jual beli (PPJB).

2. Tanggungjawab Para Pihak Atas Kesepakatan Dalam Perjanjian Pengikatan Jual Beli, Yang Dibuat Di hadapan Notaris adalah penjual adalah penjual mempunyai bertanggungjawab untuk melengkapi syarat-syarat yang belum dipenuhi untuk dilakukannya jual beli. Syaratsyarat tersebut juga harus dilengkapi oleh penjual sebagai pemegang hak dan penjual bertanggungjawab memenuhinya dan pembeli mempunyai tanggungjawab untuk melunasi sisa pembayaran jual beli kepada penjual apabila penjual telah melengkapi persyaratan yang menyebabkan belum bisa dilakukan jual beli di hadapan PPAT.

3. Bentuk Pertanggungjawaban Notaris dalam sengketa Para Pihak terkait Perjanjian Pengikatan Jual Beli (PPJB) yang dibuatnya adalah tanggung jawab notaris secara perdata atas akta yang dibuatnya, tanggung jawab notaris secara pidana atas akta yang dibuatnya. Pertanggung jawaban terhadap akta PPJB yang dibuatnya, notaris dapat dipanggil untuk menghadiri sidang pada Pengadilan Negeri tetapi notaris juga harus merahasiakan terhadap akta yang dibuatnya sesuai dengan sumpah/janji jabatan kecuali undangundang yang menentukan.

\section{DAFTAR PUSTAKA}

Abdul Kadir Muhammad, Hukum dan Penelitian Hukum, PT. Aditya Bakti, Bandung.

Alfiansyah, (2015), Urgensi Perjanjian Pengikatan Jual Beli (PPJB) Hak Atas Tanah Yang Dibuat Oleh Notaris, Jurnal Hukum, Program Studi Magister Kenotariatan, Pascasarjana Fakultas Hukum Universitas Brawijaya, 1-21.

Annisa, (2019). Tanggung Jawab Notaris Yang Tidak Mendaftarkan dan Melaporkan Akta Wasiat Ke Daftar Pusat Wasiat. Syiah Kuala Law Jurnal, 3 (1), 1-17

Ariy Yandillah, (2015). Tanggung Jawab

Notaris Pengganti Terkait

Pembuatan Akta Notaris Yang

Merugikan Para Pihak Akibat Kelalaianya. Jurnal hukum, 5 (1), 122.

Baswedan, T. B. T. (2014). Kajian Yuridis Pembatalan Akta Pengikatan Jual Beli (PJB) Tanah yang Dibuat Dihadapan Notaris. Premise Law Jurnal, 4 (1), 1-18.

Benny Krestian Heriawanto, 2018. Kewajiban Menyimpan Protocol Notaris dan Akibat Hukumnya Menurut Hukum Positif Indonesia. Arena Hukum, 11 (1), 101-118.

Dwi Apriliana, (2018). Keabsahan Akta Jual Beli Tanah Yang Dibuat Berdasarkan Kuasa Menjual Yang Telah Dibatalkan Para Pihak (Analisis Putusan Pengadilan Negeri Denpasar Nomor 347/Pdt.G/2014/PN.Dps). Jurnal Pro Hukum, 7 (2), 1-12. 
Habib Adjie, 2008, Sanksi Perdata dan Administritif Terhadap Notaris Sebagai Pejabat Publik, PT. Refika Aditama, Bandung. 2009, Meneropong Khasanah Notaris dan PPAT Indonesia, Citra Aditya Bakti, Bandung.

Jhony Ibrahim, 2006, Teori dan Metodologi Penelitian Hukum Normatif, Bayu Media Publishing, Malang.

Kadek Dio Anjasmara, (2019). Pertanggungjawaban Notaris Sebagai Penerima Titipan Sertifikat Hak Milik Atas Tanah Milik Klien, Jurnal Ius, 7 (2), 207-224.

Kunni Afifah, (2017), Tanggung Jawab dan Perlindungan Hukum Bagi Notaris Secara Perdata Terhadap Akta Yang Dibuatnya. Lex Renaissance, 1 (2), 147-161.

Laurensius Arliman S, (2016), Pemanggilan Notaris Dalam Rangka Penegakan Hukum Paska Perubahan Undang-Undang Jabatan Notaris. Justitia et Pax, 32 (1), 1-15.

Muchlis Patahna, 2009, Problematika Notaris, Rajawali, Jakarta, 2009.

Nisaul Hasanah, (2018), Pengawasan Pengurus Ikatan Notaris Indonesia Kota Padang Terhadap Pelaku Pelanggaran Kode Etik. Jurnal Cita Hukum, 6, (2), 361-386.

Nur Aini, (2019), Tanggung Jawab Notaris Atas Keterangan Palsu Yang Disampaikan Penghadap Dalam Akta Pendirian Perseroan Terbatas. Jurnal Undiksha, 5 (2), 105-116.
Rahmawati Boty, (2017). Kekuatan Akta Notaris Dalam Menjamin Hak Keperdataan. Jurnal Cendekia Hukum, 3 (1). 85-98.

Rita Alfiana, (2018). Ambiguitas Bentuk Akta Notaris (Analisis UndangUndang Tentang Jabatan Notaris dan Kitab Undang-Undang Hukum Perdata). Lex Jurnalica, 15 (3), 299307.

Rizki Nurmayanti, (2017). Peran Dan Tanggung Jawab Notaris Dalam Pelaksanaan Pembuatan Akta Koperasi. Jurnal Akta, 4 (4), 609623.

R. Setiawan, 2005, Pokok-Pokok Hukum Perikatan, Bina Cipta, Jakarta.

Rusdianto, Dony Hadi, 2009, Beberapa Catatan Penting Tentang Pengikatan Jual-Beli Hak Atas Tanah, Rineka Cipta, Jakarta.

Santia Dewi, R.M Fauwas Diradja, 2011, Panduan Teori dan Praktik Notaris, Buku Seru, Jakarta.

Silviana, A., (2017). Legalitas Kuasa Dalam Akta Pengikatan Jual Beli Tanah Sebagai Dasar Pembuatan Akta Jual Beli (Studi di Kota Semarang). Diponegoro Law Review, 6 (1), 1-11.

Sjaifurrachman, 2011, Aspek Pertanggungjawaban Notaris dalam Pembuatan Akta, Mandar Maju, Bandung.

Tengku Erwinsyahbana, (2018), Kewenangan dan Tanggung Jawab Notaris Pengganti setelah Pelaksanaan Tugas dan Jabatan Berakhir. Lentera Hukum, 5 (2), 305-321. 
Aulia Gumilang Rosadi: Tanggung Jawab Notaris Dalam Sengketa Para Pihak Terkait...

Triyanto Setyo Prabowo, (2017), Dalam Konsolidasi Tanah, Raja Tanggung Jawab Calon Notaris Grafindo Persada, Jakarta.

Yang Sedang Magang Terhadap

Kerahasiaan Akta. Jurnal

Repertorium, 4 (2), 70-78.

Yudhi Setiawan, 2009, Instrumen Hukum

Campuran (Gemeenschapelijkt)

Zulkifli Harahap, (2011). Pemanggilan Seorang Notaris dan PPAT oleh Kepolisian Harus Seizin Majelis Pengawas Daerah, Majalah Renvoi, Edisi Mei 2011. 